\title{
SCREENING AND MORPHOLOGICAL OBSERVATIONS OF ENDOPHYTIC MOLD ORIGIN OF PENNYWORT (Centella asiatica (L.) Urban) AS EXTRACELLULAR ENZYME PRODUCER
}

\author{
Muhamad Aditya Hidayah*, Retno Aliyatul Fikroh
}

Pendidikan Kimia, Fakultas Ilmu Tarbiyah dan Keguruan, UIN Sunan Kalijaga

Jl. Laksada Adisucipto, Depok-Sleman, Daerah Istimewa Yogyakarta 55281, Indonesia

\author{
ARTICLE INFO \\ Article history: \\ Received 05 Mar 2021, \\ Revised 21 Mei 2021, \\ Accepted 07 Jun 2021 \\ Available online 30 July 2021

$$
\begin{array}{ll}
\text { Keywords: } \\
\checkmark & \text { Centella asiatica (L.) } \\
& \text { Urban } \\
\checkmark & \text { extracellular enzymes } \\
\checkmark & \text { endophytic typite } \\
\checkmark & \text { isolates }
\end{array}
$$

*corresponding author: 20104060025@student.uinsuka.ac.id

Phone: +6281357944476

Doi: https://doi.org/10.31938/jsn.v $\underline{11 \mathrm{i} 2.304}$

\begin{abstract}
Pennywort is a biological plant that is included in the medicinal plant species. The analysis was carried out to obtain information and to find out that endophytic molds from pennywort (Centella asiatica (L.) Urban) can produce extracellular enzymes (amylase, cellulase, pectinase, protease, glucanase, and laccase). Based on the analysis that has been carried out, several conclusions are obtained, endophytic fungi from pennywort with isolate codes MB 20, MM 1, MM 6, MM 8, and MM 16 capable of producing extracellular amylase enzymes, endophytic fungi from pennywort with isolate codes MM 1, MM 12, MM 16, MM 18, MM 19, MM 20 and MM 21 were able to produce extracellular cellulase enzymes, endophytic fungi from pennywort with isolate codes $M B 1, M B 3, M B 4, M B 6$, MM 1, MM 9, MM 11, MM 13, MM 14, MM16, MM 19, MM 20 and MM 21 were able to produce extracellular glucanase enzymes, endophytic mold isolates from pennywort were proven to be unable to produce extracellular enzymes laccase, pectinase, and protease, and endophytic molds from pennywort with isolate codes $M B$ 1, MB 20, MM 14 and the MM 16 is capable of producing siderophores.
\end{abstract}

\section{ABSTRAK}

Skrining pengamatan morfologi kapang endofit asal tanaman pegagan (Centella asiatica (L.) Urban) sebagai penghasil enzim ekstraseluler

Tanaman pegagan merupakan tanaman hayati yang termasuk dalam jenis tanaman obat Analisis dilakukan untuk mendapatkan informasi dan mengetahui bahwa kapang endofit asal tanaman pegagan (Centella asiatica (L.) Urban) dapat menghasilkan enzim ekstraseluler (Amilase, selulase, pektinase, protease, glukanase, dan lakase). Berdasarkan analisis yang telah dilakukan di peroleh beberapa kesimpulan, diantanya. yaitu kapang endofit asal tanaman pegagan dengan kode isolat MB 20, MM 1, MM 6, MM 8 dan MM 16 mampu menghasilkan enzim amilase ekstraseluler, kapang endofit asal tanaman pegagan dengan kode isolat MM 1, MM 12, MM 16, MM 18, MM 19, MM 20 dan MM 21 mampu menghasilkan enzim selulase ekstraseluler, kapang endofit asal tanaman pegagan dengan kode isolat MB 1, MB 3, MB 4, MB 6, MM 1, MM 9, MM 11, MM 13 , MM 14, MM16, MM 19, MM 20 dan MM 21 mampu menghasilkan enzim glukanase ekstraseluler, isolat kapang endofit asal tanaman pegagan terbukti tidak mampu menghasilkan enzim ekstraseluler lakase, pektinase dan protease, dan kapang endofit asal tanaman pegagan dengan kode isolat MB 1, MB 20, MM 14 dan MM 16 mampu menghasilkan siderofor.

Kata Kunci : Centella asiatica (L.) Urban, enzim ekstraseluler, kapang endofit, isolat

\section{PENDAHULUAN}

Indonesia merupakan negara yang memiliki kekayaan hayati flora dan fauna yang tinggi. Disamping itu, Indonesia juga memiliki kekayaan mikroba yang tidak kasat mata, salah satunya adalah kapang endofit. Kapang endofit adalah mikroorganisme yang hidup bersimbiosis dalam jaringan tumbuhan. Seluruh atau sebagian siklus hidupnya berlangsung didalam jaringan tumbuhan dan mampu membentuk koloni didalam jaringan tumbuhan tanpa merugikan tumbuhan inangnya (Murdiyah, 2017). Kapang endofit terdapat pada hampir semua jaringan 
tumbuhan seperti daun, batang, akar dan biji (Latifasari et al., 2019). Kapang endofit berperan dalam meningkatkan pertumbuhan tanaman, karena pada kapang endofit terdapat enzim. Manfaat enzim untuk organisme adalah sebagai biokatalisator, yang berfungsi untuk mempercepat berlangsungnya reaksi biologis tanpa terkonsumsi atau berubah dan tidak ikut bereaksi (Pelczar, 2019).

Beberapa peneliti telah berhasil melakukan penapisan enzim ekstraseluler dari kapang endofit, yaitu enzim amilase, selulase, glukanase, pektinase (Choi et al., 2005), lakase (Rana et al., 2019),, protease (Sunitha et al., 2013), dan asparaginase (Theantana et al., 2009). Penelitian Devi et al. (2012) menunjukkan bahwa kapang Pennicilium sp. mampu menghasilkan enzim selulase dari tanaman pegagan. Beberapa jenis kapang endofit telah berhasil diisolasi dari tanaman pegagan aksesi Bengkulu dan Malaysia oleh Gupta dan Chaturvedi (2017). Jenis-jenis kapang endofit yang berhasil diperoleh adalah Acremonium sp., Acrocalymma aquatica, Acrocalymma vagum, Aspergillus flavus, Aspergillus versicolor, Ceratobasidium sp., Ceratobasidium sp., Chaetomium globosum, Colletotrichum coccodes, Colletotrichum destructivum, Colletotrichum gloeosporioides, Colletotrichum siamense, Colletotrichum sp., Earliella scabrosa, Eutypella scoparia, Fusarium oxysporum, Fusarium solani, Fusarium sp., Fusarium striatum, Helotiales sp., Penicillium capsulatum, Perenniporia sp., Perenniporia sp., Phanerochaete chrysosporium, Phanerochaete chrysosporium, Phoma multirostrata, Phomopsis asparagi, Phyllosticta capitalensis, Talaromyces pinophilus, dan Trichaptum sp.

Tanaman pegagan merupakan tanaman hayati yang termasuk dalam jenis tanaman obat. Tanaman ini banyak ditemukan di Indonesia, dan sering digunakan sebagai ramuan dalam tanaman obat (Bermawie et al., 2008). Muhlisah (2007) dan Mainawati et al. (2017) menjelaskan bahwa pegagan adalah tumbuhan merambat dengan rimpang yang pendek. Batangnya panjang dan berwarna coklat. Daun pegagan berbentuk tunggal dan berbentuk seperti ginjal dan tumbuh di lingkungan yang sedikit lembab. Tanaman dari Asia ini biasanya ditemukan tumbuh di alam liar di padang rumput, persawahan bahkan di pekarangan.

Tanaman pegagan (Centella asiatica (L.) Urban) merupakan salah satu inang kapang endofit yang telah lama digunakan di dunia kesehatan. Morfologi tumbuhan pegagan memiliki keunikan tersendiri di setiap daerah. Perbedaan faktor lingkungan, klasifikasi dan latar belakang genetik tanaman sangat erat kaitannya dengan struktur komunitas dan sebaran kapang endofit tanaman inang (Jia et al., 2016). Oleh karena itu, dilakukan penelitian tentang potensi kapang endofit aksesi Malaysia (MM) dan Bengkulu (MB) untuk menghasilkan enzim ekstraseluler. Enzim ekstraseluler yang dihasilkan diharapkan dapat menjadi sumber enzim ekstraseluler baru yang berasal dari kapang endofit tanaman pegagan (Centella asiatica (L.) Urban).

\section{BAHAN DAN METODE}

\section{Bahan dan Alat}

Bahan-bahan yang digunakan dalam skrining kapang endofit asal tanaman pegagan (Centella asiatica (L.) urban) sebagai penghasil enzim ekstraseluler antara lain : $\left(\mathrm{NH}_{4}\right)_{2} \mathrm{SO}_{4}, \alpha-$ naftol, agar, akuabides, akuades, alkohol 70\%, alumunium foil, ammonium sulfat, asam Casamino, Bacto agar, $\mathrm{CaCl}_{2}$, Carboxy Methyl Cellulos (CMC), Chloramphenicol, Chrome Azurol Sulfonate (CAS), congo red, etanol teknis, $\mathrm{FeCl}_{3} \cdot 6 \mathrm{H}_{2} \mathrm{O}$, gelatin, glukosa, $\mathrm{HCl}$, hexadecyl trimethyl ammonium bromide, iodin, isolat kapang Endofit pegagan, kapang endofit tanaman pegagan dengan kode isolat : MB1; MB3; MB4; MB5; MB6; MB8; MB11; MB12; MB15; MB17; MB18; MB19; MB20; MB21; MM1; MM2; MM6; MM7; MM8; MM9; MM11; MM12; MM13; MM14; MM15; MM16; MM17; MM19; MM20; MM21; MM22; dan MM23 (MB untuk Aksesi Bengkulu dan MM untu Aksesi Malaysia), $\mathrm{KCl}$, kentang, kertas, $\mathrm{KH}_{2} \mathrm{PO}_{4}$, KI, korek kayu, label kertas, lacto cotton blue, media PDA (Potato Dextrose Agar), $\mathrm{MgSO} 4, \mathrm{MgSO} 4.7 \mathrm{H} 2 \mathrm{O}$, Minimal Media 9 (MM 9), $\mathrm{NaCl}, \mathrm{NaHPO}_{4}, \mathrm{NaNO}_{3}, \mathrm{NaOH}, \mathrm{NH}_{4} \mathrm{Cl}$, pektin, pepton, PIPES, sedotan plastik, soluble starch, subract glukan, tissue, tusuk gigi steril, dan yeast extract.

Alat-alat yanng digunakan adalah autoklaf, beaker glass $500 \mathrm{~mL}$, botol semprot, bunsen, cawan petri, labu Erlenmeyer $1000 \mathrm{~mL}$, jarum ose, laminar air flow, magnetic stirrer, microwave, mikroskop, milipore, object glass, oven, parafilm, pinset, pipet mikro, spatula, timbangan analitik, dan tip pipet $1 \mathrm{~mL}$. 


\section{Metode}

Penelitian ini merupakan penelitian eksperimental yang menghasilkan data kualitatif dan data kuantitatif. Data kualitatif meliputi hasil dari masing-masing pengujian yang mengandalkan pengamatan visual dari keberadaan zona bening dan pengamatan bentuk dengan menggunakan mikroskop. Data Kuantitatif yang dihasilkan adalah diameter zona bening untuk menunjukkan indeks aktivitas enzim ekstraseluler.

\section{Sterilisasi Alat}

Alat-alat gelas berbahan gelas seperti cawan petri dicuci menggunakan detergen, kemudian alat-alat yang sudah kering dibungkus menggunakan kertas dan dimasukan bersamaan dengan tusuk gigi dan sedotan yang telah dipotong pendek kedalam autoklaf. Lalu, sterilkan dalam autoklaf pada suhu $121^{\circ} \mathrm{C}$ selama 15 menit dengan tekanan $1 \mathrm{~atm}$. Namun, jarum ose dan pinset disterilisasi dengan cara dipijarkan pada nyala api bunsen, sedangakan ruang inokulasi (Laminar Air Flow) disterilisasi menggunakan larutan alkohol $70 \%$ dan sinar UV.

\section{Peremajaan Kapang Endofit Tanaman Pegagan pada Media Potato Dextrose Agar (PDA)}

Media PDA dituangkan ke dalam cawan petri, kemudian bagian tengah media di cork borrer menggunakan sedotan steril. Selanjutnya, isolat kapang endofit tanaman pegagan yang telah di cork borrer di pindahkan menggunakan tusuk gigi steril ke dalam media PDA yang sudah di cork borrer bagian tengahnya, lalu inkubasi pada suhu ruang.

\section{Pembuatan Media Pengujian Kapang Endofit Asal Tanaman Pegagan Sebagai Penghasil Enzim Ekstraseluler}

\section{Pembuatan Media Selektif Glucose Yeast Peptone (GYP)}

Glucose sebanyak 0,5 gram, yeast extract 0,025 gram, peptone 0,25 gram dan soluble starch sebanyak 0,5 gram,ditimbang kemudian dilarutkan dengan akuades sebanyak $500 \mathrm{~mL}$ ke dalam beaker glass $1000 \mathrm{~mL}$ sambil dihomogenisasi menggunakan magnetic stirrer hingga semua bahan larut. $\mathrm{pH}$ larutan diatur menjadi 6, kemudiam larutan di pindahkan ke dalam labu Erlenmeyer $1000 \mathrm{~mL}$ dan bacto agar ditambahkan sebanyak 10 gram, ditutup dengan alumunium foil. Medium GYP disterilkan menggunakan autoklaf suhu $121^{\circ} \mathrm{C}$ selama 15 menit dengan tekanan 1 atm. Setelah steril, medium GYP dituangkan ke dalam cawan petri steril dan ditunggu hingga memadat.

\section{Pembuatan Media Selektif Glukan}

$\mathrm{NaHPO}_{4}$ sebanyak 0,325 gram, $\mathrm{KH}_{2} \mathrm{PO}_{4}$ 0,75 gram, $\mathrm{NaCl} 1,25$ gram, $\left(\mathrm{NH}_{4}\right)_{2} \mathrm{SO}_{4} 0,25$ gram, $\mathrm{MgSO}_{4} .7 \mathrm{H}_{2} \mathrm{O}$ 0,06 gram, $\mathrm{CaCl}_{2} 0,025$, peptone 0,625 gram, yeast extract 0,25 gram, bacto agar 10 gram, dan subtract glukan sebanyak 5 gram ditimbang, kemudian dilarutkan dengan akuades sebanyak $500 \mathrm{~mL}$ ke dalam erlenmyer $1000 \mathrm{~mL}$, larutan dihomogenkan menggunakan magnetic stirrer hingga semua bahan larut kemudian ditutup dengan alumunium foil. Selanjutnya, media glukan disterilkan menggunaan autoklaf pada suhu $121^{\circ} \mathrm{C}$ selama 15 menit dengan tekanan $1 \mathrm{~atm}$. Medium glukan yang telah steril dituangkan ke dalam cawan petri steril dan ditunggu hingga memadat.

\section{Pembuatan Media Selektif Lakase}

Glucose sebanyak 0,5 gram, yeast extract 0,025 gram, peptone 0,25 gram dan $\alpha$-naftol 0,025 gram ditimbang, kemudian dilarutkan dengan akuades sebanyak $500 \mathrm{~mL}$ ke dalam beaker glass $1000 \mathrm{~mL}$ sambil dihomogenisasi menggunakan magnetic stirrer. $\mathrm{pH}$ larutan diatur menjadi 6, lalu larutan dipindahkan ke dalam labu Erlenmeyer $1000 \mathrm{~mL}$ dan bacto agar ditambahkan sebanyak 10 gram, lalu ditutup dengan alumunium foil. Disterilkan medium lakase menggunaan autoklaf suhu $121^{\circ} \mathrm{C}$ selama 15 menit dengan tekanan $1 \mathrm{~atm}$. Setelah steril, medium lakase dituangkan ke dalam cawan petri steril dan ditunggu hingga memadat.

\section{Pembuatan Media Selektif Pektin}

Pektin sebanyak 2,5 gram ditimbang dan dilarutkan dengan akuades $100 \mathrm{~mL}$ pada suhu $60^{\circ} \mathrm{C}$ sambil dipanaskan diatas hotplate. Kemudian, larutan pektin dimasukkan ke dalam beaker glass $500 \mathrm{~mL}$ dan akuades ditambahkan sebanyak $400 \mathrm{~mL}$. Yeast extract sebanyak 0,5 gram ditimbang dan ditambahkan sambil dihomogenisasi menggunakan magnetic stirrer hingga semua bahan larut. $\mathrm{pH}$ larutan diatur menjadi 5, kemudiam larutan dipindahkan ke dalam labu Erlenmeyer $1000 \mathrm{~mL}$ dan bacto agar ditambahkan sebanyak 10 gram, lalu ditutup dengan alumunium foil. Medium pektin disterilkan menggunaan autoklaf suhu $121^{\circ} \mathrm{C}$ selama 15 menit dengan tekanan $1 \mathrm{~atm}$. Setelah 
steril, medium pektin dituangkan ke dalam cawan petri steril dan ditunggu hingga memadat.

\section{Pembuatan Media Selektif Protease}

Gelatin sebanyak 2 gram ditimbang dan dilarutkan dengan akuades $100 \mathrm{~mL}$ pada suhu $60^{\circ} \mathrm{C}$ sambil dipanaskan diatas hotplate. Kemudian, larutan gelatin dimasukkan ke dalam beaker glass $500 \mathrm{~mL}$ dan akuades ditambahkan sebanyak $400 \mathrm{~mL}$. Yeast extract 0,05 gram dan pepton 0,25 gram ditimbang dan ditambahkan sambil dihomogenisasi menggunakan magnetic stirrer. $\mathrm{pH}$ larutan diatur menjadi 6, kemudiam larutan dipindahkan ke dalam labu Erlenmeyer $1000 \mathrm{~mL}$ dan bacto agar ditambahkan sebanyak 10 gram, lalu ditutup dengan alumunium foil. Medium protease disterilkan menggunaan autoklaf suhu $121^{\circ} \mathrm{C}$ selama 15 menit dengan tekanan 1 atm. Setelah steril, medium protease dituangkan ke dalam cawan petri steril dan ditunggu hingga memadat.

\section{Pembuatan Media Selektif Carboxy Methyl Cellulose (CMC)}

Carboxyl Methyl Cellulose (CMC ) sebanyak 5 gram ditimbang dan dilarutkan dengan akuades $200 \mathrm{~mL}$ pada suhu $60^{\circ} \mathrm{C}$ sambil dipanaskan diatas hotplate. Kemudian, larutan CMC dimasukkan ke dalam erlenmeyer $1000 \mathrm{~mL}$ dan akuades ditambahkan sebanyak $300 \mathrm{~mL}$. Yeast extract sebanyak 0,25 gram, $\left(\mathrm{NH}_{4}\right)_{2} \mathrm{SO}_{4} 0,5$ gram, $\mathrm{NaNO}_{3} 1$ gram, $\mathrm{KH}_{2} \mathrm{PO}_{4} 0,5$ gram, $\mathrm{MgSO}_{4}$ 0,25 gram, $\mathrm{KCl} 0,25$ gram, dan bacto agar sebanyak 10 gram ditambahkan sambil dihomogenisasi menggunakan magnetic stirrer hingga semua bahan larut dan ditutup dengan alumunium foil. Kemudian, medium selulase disterilkan menggunaan autoklaf suhu $121^{\circ} \mathrm{C}$ selama 15 menit dengan tekanan $1 \mathrm{~atm}$. Setelah steril, medium selulase dituangkan ke dalam cawan petri steril dan ditunggu hingga memadat.

\section{Pengujian Kapang Endofit Asal Tanaman Pegagan Sebagai Penghasil Enzim Ekstraseluler}

\section{Pengujian Amilase Ekstraseluler}

Sebanyak 5 isolat kapang endofit tanaman pegagan yang telah diremajakan disiapkan untuk pengujian. Bagian tengah media GYP di cork borrer menggunakan sedotan (sedotan diambil menggunakan pinset yang telah dipijarkan sebelumnya pada nyala api bunsen). Isolat kapang endofit yang telah disiapkan di cork borrer untuk dipindahkan ke dalam media GYP yang sudah di cork borrer bagian tengahnya menggunakan tusuk gigi steril. Tepi cawan dipijarkan pada nyala api bunsen dan tutup menggunakan parafilm. Diinkubasi selama 5 hari, setelah 5 hari diberikan larutan iodin $1 \%$ dalam kalium iodida $2 \%$ sebanyak $2 \mathrm{~mL}$ dan inkubasi selama 48 jam untuk menyempurnakan pembentukan zona bening. Indeks aktivitas amilase ditentukan dengan cara mengukur diameter zona bening dan diameter koloni.

\section{Pengujian Glukanase Ekstraseluler}

Sebanyak 19 isolat kapang endofit tanaman pegagan yang telah diremajakan disiapkan untuk pengujian. Bagian tengah media glukan di cork borrer menggunakan sedotan (sedotan diambil menggunakan pinset yang telah dipijarkan sebelumnya pada nyala api bunsen). Isolat kapang endofit yang telah disiapkan di cork borrer untuk dipindahkan ke dalam media glukan yang sudah di cork borrer bagian tengahnya menggunakan tusuk gigi steril. Tepi cawan dipijarkan pada nyala api bunsen dan tutup menggunakan parafilm. Diinkubasi selama 6 hari, setelah 6 hari diberikan larutan congo red $0,3 \%$ sebanyak $2 \mathrm{~mL}$ lalu dibilas dengan larutan $\mathrm{NaCl} 0,1 \%$ dan inkubasi selama 48 jam untuk menyempurnakan pembentukan zona bening. Indeks aktivitas glukanase ditentukan dengan cara mengukur diameter zona bening dan diameter koloni.

\section{Pengujian Lakase Ekstraseluler}

Sebanyak 12 isolat kapang endofit tanaman pegagan yang telah diremajakan disiapkan untuk pengujian. Bagian tengah media lakase di cork borrer menggunakan sedotan (sedotan diambil menggunakan pinset yang telah dipijarkan sebelumnya pada nyala api bunsen). Isolat kapang endofit yang telah disiapkan di cork borrer untuk dipindahkan ke dalam media lakase yang sudah di cork borrer bagian tengahnya menggunakan tusuk gigi steril. Tepi cawan dipijarkan pada nyala api bunsen dan tutup menggunakan parafilm. Diinkubasi selama 5 hari, setelah 5 hari diberikan larutan napthol $0,005 \%$ sebanyak $2 \mathrm{~mL}$ dan inkubasi selama 48 jam untuk menyempurnakan pembentukan zona bening. Indeks aktivitas lakase ditentukan dengan cara mengukur diameter zona bening dan diameter koloni.

\section{Pengujian Pektinase Ekstraseluler}

Sebanyak 13 isolat kapang endofit tanaman pegagan yang telah diremajakan disiapkan untuk 
pengujian. Bagian tengah media pektinase di cork borrer menggunakan sedotan (sedotan diambil menggunakan pinset yang telah dipijarkan sebelumnya pada nyala api bunsen). Isolat kapang endofit yang telah disiapkan di cork borrer untuk dipindahkan ke dalam media pektinase yang sudah di cork borrer bagian tengahnya menggunakan tusuk gigi steril. Tepi cawan dipijarkan pada nyala api bunsen dan tutup menggunakan parafilm. Diinkubasi selama 5 hari, setelah 5 hari diberikan larutan hexadecyl trimetil ammonium bromida $1 \%$ sebanyak $2 \mathrm{~mL}$ dan inkubasi selama 24 jam untuk menyempurnakan pembentukan zona bening. Indeks aktivitas pektinase ditentukan dengan cara mengukur diameter zona bening dan diameter koloni.

\section{Pengujian Protease Ekstraseluler}

Sebanyak 9 isolat kapang endofit tanaman pegagan yang telah diremajakan disiapkan untuk pengujian. Bagian tengah media protease di cork borrer menggunakan sedotan (sedotan diambil menggunakan pinset yang telah dipijarkan sebelumnya pada nyala api bunsen). Isolat kapang endofit yang telah disiapkan di cork borrer untuk dipindahkan ke dalam media protease yang sudah di cork borrer bagian tengahnya menggunakan tusuk gigi steril. Tepi cawan dipijarkan pada nyala api bunsen dan tutup menggunakan parafilm. Diinkubasi selama 5 hari, setelah 5 hari diberikan ammonium sulfat jenuh sebanyak $2 \mathrm{~mL}$ dan inkubasi selama 24 jam untuk menyempurnakan pembentukan zona bening. Indeks aktivitas protease ditentukan dengan cara mengukur diameter zona bening dan diameter koloni.

\section{Pengujian Selulase Ekstraseluler}

Sebanyak 10 isolat kapang endofit tanaman pegagan yang telah diremajakan disiapkan untuk pengujian. Bagian tengah media selulase di cork borrer menggunakan sedotan (sedotan diambil menggunakan pinset yang telah dipijarkan sebelumnya pada nyala api bunsen). Isolat kapang endofit yang telah disiapkan di cork borrer untuk dipindahkan ke dalam media selulase yang sudah di cork borrer bagian tengahnya menggunakan tusuk gigi steril. Tepi cawan dipijarkan pada nyala api bunsen dan tutup menggunakan parafilm. Diinkubasi selama 5 hari, setelah 5 hari diberikan pewarna Congo Red $0,3 \%$ sebanyak $2 \mathrm{~mL}$ kemudian dibilas dengan larutan $\mathrm{NaCl} 0,1 \%$ dan inkubasi selama 24 jam untuk menyempurnakan pembentukan zona bening. Indeks aktivitas selulase ditentukan dengan cara mengukur diameter zona bening dan diameter koloni.

\section{Deteksi Siderofor yang Dihasilkan oleh Kapang Endofit Tanaman Pegagan (Centella asiatica (L.) Urban)}

\section{Pembuatan Media Chrome Azurol Sulfonate (CAS) \\ Pewarna Biru}

Pembuatan larutan A dibuat dengan cara Chrome Azurol Sulfonate (CAS) sebanyak 0,06 gram dilarutkan ke dalam $50 \mathrm{~mL}$ akuades, larutan $B$ dibuat dengan cara $\mathrm{FeCl}_{3} \cdot 6 \mathrm{H}_{2} \mathrm{O}$ sebanyak 0,0027 gram dilarutkan ke dalam 10 $\mathrm{mL} \mathrm{HCl} 10 \mathrm{M}$, dan untuk larutan $\mathrm{C}$ dibuat dengan cara Hexadecyl trimethyl ammonium bromide sebanyak 0,073 gram dilarutkan ke dalam $40 \mathrm{~mL}$ akuades. Larutan A $(50 \mathrm{~mL})$, larutan B $(9 \mathrm{~mL})$, dan larutan C $(40 \mathrm{~mL})$ dicampurkan untuk membuat pewarna biru. Larutan pewarna disterilkan menggunaan autoklaf suhu $121^{\circ} \mathrm{C}$ selama 15 menit dengan tekanan $1 \mathrm{~atm}$.

\section{Larutan campuran}

Larutan campuran terdiri dari stok larutan garam Minimal Media 9 (MM 9), stok glukosa $20 \%$, stok $\mathrm{NaOH}$, dan larutan asam casamino. Pembuatan stok larutan garam Minimal Media 9 $\left(\mathrm{MM}\right.$ 9) dilakukan dengan cara $\mathrm{KH}_{2} \mathrm{PO}_{4}$ sebanyak 15 gram, $\mathrm{NaCl} 25$ gram, dan $\mathrm{NH}_{4} \mathrm{Cl} 50$ gram dilarutkan dalam $500 \mathrm{~mL}$ akuades. Pembuatan stok larutan glukosa 20\% dilakukan dengan cara glukosa sebanyak 20 gram dilarutkan dalam $100 \mathrm{~mL}$ akuades. Stok larutan $\mathrm{NaOH}$ dibuat dengan cara $\mathrm{NaOH}$ sebanyak 25 gram dilarutkan dalam $150 \mathrm{~mL}$ akuades, $(\mathrm{pH} 12)$. Larutan asam casamino dibuat dengan cara asam casamino sebanyak 3 gram dilarutkan dalam 27 $\mathrm{mL} \mathrm{H}_{2} \mathrm{O}$, kemudian di sterilisasi menggunakan filter milipore.

\section{Persiapan Agar CAS}

Larutan MM9 sebanyak $100 \mathrm{~mL}$ diarutkan ke dalam $750 \mathrm{~mL}$ akuades, piperazine-N, N'bis(2-ethanesulfonic acid) PIPES ditambahkan sebanyak 32,24 gram. Kemudian, $\mathrm{pH}$ diatur menjadi $\mathrm{pH}$ 6,8. Selanjutnya, bacto agar sebanyak 15 gram ditambahkan dan disterilisasi dengan autoklaf lalu didinginkan hingga suhu 50 ${ }^{0} \mathrm{C}$. Setelah steril, larutan asam casamino steril sebanyak $27 \mathrm{~mL}$, larutan glukosa $20 \% 10 \mathrm{~mL}$, 
dan pewarna biru $100 \mathrm{~mL}$ ditambahkan dan kemudian tuang ke cawan petri yang sudah steril.

\section{Pengujian Siderofor}

Isolat kapang endofit pegagan yang akan di uji dan telah diremajakan disiapkan untuk pengujian, sterilisasi Laminar Air Flow(LAF) dengan alkohol $70 \%$, alat bahan yang akan digunakan dimasukan kedalam LAF. Kemudian, media CAS di cork borrer pada bagian tengah menggunakan sedotan. Setelah itu, hasil cork borrer isolat dipindahkan menggunakan tusuk gigi steril ke dalam media CAS yang sudah di cork borrer bagian tengahnya. Tepi cawan dipijarkan pada nyala api bunsen dan ditutup tepi cawan menggunakan parafilm. Inkubasi dilakukan selama 5 hari dan dilakukan pengamatan terhadap zona bening. Indeks aktivitas siderofor ditentukan dengan cara mengukur diameter zona bening dan diameter koloni.

\section{Pengamatan Mikroskopis Kapang Endofit Tanaman Pegagan}

Isolat kapang endofit tanaman pegagan serta alat dan bahan yang akan digunakan disiapkan untuk pengujian, sebelum pengmatan object glass dibersihkan menggunakan alkohol $70 \%$ kemudian diseka/lap dengan tisu. Kemudian, setetes Lacto cotton blue diteteskan diatas object glass menggunakan pipet, sedikit isolat diambil menggunakan tusuk gigi kemudian diratakan di permukaan object glass bersamaan dengan larutan Lacto cotton blue. Selanjutnya, object glass ditetesi etanol teknis, kemudian ditutup dengan cover glass. Object glass difiksasi dengan nyala api bunsen dan amati menggunakan mikroskop.

\section{HASIL DAN PEMBAHASAN}

\section{Uji Kapang Eendofit Penghasil Enzim Amilase secara Kualitatif \\ Uji aktivitas amilolitik kapang endofit secara kualitatif menggunakan media agar}

selektif, dengan cara inokulasi. Uji aktivitas amilolitik dapat diketahui ada atau tidaknya berdasarkan adanya zona bening disekitar isolat pada media agar selektif setelah penambahan iodin. Kemampuan kapang endofit dalam menghasilkan zona bening menunjukan bahwa kapang endofit dapat menghasilkan enzim amilase. Iodin yang bereksi dengan pati akan menghasilkan senyawa kompleks berwarna ungu. Zona bening yang terdapat disekitar koloni mengindikasikan bahwa pati pada media agar selektif telah terhidrolisis oleh isolat. Pati yang terhidrolisis terbentuk menjadi senyawa yang lebih sederhana yaitu glukosa. Sedangkan media yang masih berwarna ungu kehitaman menunjukan pati pada media tersebut belum terhidrolisis.

Uji aktivitas amilase kapang endofit menunjukan kelima isolat dapat memperlihatkan zona bening ketika dilakukan penambahan larutan iodin, karena pada zona tersebut pati sudah terhidrolisis menjadi senyawa yang lebih sederhana seperti disakarida atau monosakarida sehingga zona bening tidak ikut terwarnai oleh larutan iodin. Bakteri termofilik memanfaatkan pati sebagai sumber karbon untuk menghasilkan energi, dan hasil perombakan pati tersebut dikarenakan adanya aktivitas enzim ekstraseluler amilase. Isolat yang mempunyai aktifitas amilolitik tersebut yaitu isolat Ceratobasidium cornigerum MB 20, Ceratobasidium sp. MM 1, Trametes sp. MM 6, Phialemonium dimorphosporum MM8, dan Talaromyces pinophilus MM 16. Hal ini membuktikan bahwa kapang endofit tersebut dapat menghasilkan enzim ekstraseluler yang bersifat termostabil.

Perbedaan zona bening yang terbentuk dari masing-masing isolat disebabkan kemampuan masing-masing isolat untuk menghidrolisis pati berbeda-beda. Angka indeks masing-masing isolat kapang endofit pada uji aktivitas amilase terlihat pada Tabel 1 dan pembentukan zona bening oleh kapang endofit penghasil enzim amilase dapat dilihat pada Gambar 1. 


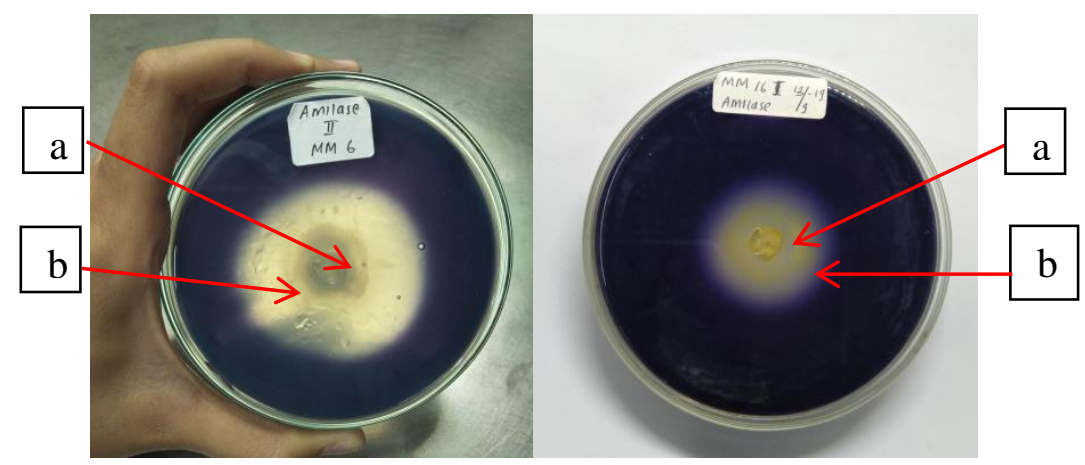

Gambar 1. Hasil positif uji aktivitas enzim amilolitik secara kualitatif isolat kapang endofit asal tanaman pegagan. ket : (a) Isolat (b) Zona bening

Tabel 1. Diameter zona bening kapang endofit penghasil enzim amilase

\begin{tabular}{|c|c|c|c|c|c|c|c|}
\hline \multirow[t]{2}{*}{ Isolat } & \multicolumn{2}{|c|}{ Hasil (+/-) } & \multicolumn{2}{|c|}{$\begin{array}{c}\text { Diameter } \\
\text { zona bening } \\
(\mathrm{cm})\end{array}$} & \multicolumn{2}{|c|}{$\begin{array}{l}\text { Diameter } \\
\text { koloni }(\mathrm{cm})\end{array}$} & \multirow[t]{2}{*}{ Indeks } \\
\hline & I & II & I & II & I & II & \\
\hline Ceratobasidium cornigerum MB 20 & + & + & 6,35 & 6,00 & 5,20 & 5,80 & 1,12 \\
\hline Ceratobasidium sp. MM 1 & + & + & 3,30 & 3,35 & 3,00 & 3,00 & 1,11 \\
\hline Trametes sp. MM 6 & + & + & 4,40 & 5,20 & 3,40 & 2,60 & 1,60 \\
\hline Phialemonium dimorphosporum MM 8 & + & + & 2,50 & 3,00 & 2,00 & 2,25 & 1,29 \\
\hline Talaromyces pinophilus MM 16 & + & + & 3,45 & 3,00 & 2,40 & 2,50 & 1,32 \\
\hline
\end{tabular}

Dilihat dari Tabel 1 berdasarkan tingginya angka indeks dari masing-masing isolat yang diamati, maka yang memiliki angka indeks tertinggi yaitu isolat Trametes sp.MM6, sedangkan isolat yang memiliki angka indeks terendah yaitu isolat Ceratobasidium sp. MM 1.

\section{Uji Kapang Endofit Penghasil Enzim Selulase secara Kualitatif}

Kemampuan isolat kapang endofit dalam menghasilkan enzim selulase dapat ditinjau dari pengujian aktivitas selulotik secara kualitatif. Analisis kualitatif aktivitas selulolitik mikroba dapat dilakukan dengan mengukur zona bening yang terbentuk disekitar koloni pada media selektif.

Metode kualitatif dalam melakukan uji aktivitas selulolitik kapang endofit menggunakan media padat Carboxil Methil Cellulosa (CMC) dengan cara inokulasi. CMC digunakan sebagai media karena berperan substrat terbaik penginduksi sintesis enzim selulase ekstraseluler kapang endofit (Rahayu et al., 2014). Adanya aktivitas selulolitik ditunjukan dengan terbentuknya zona bening pada media CMC setelah penambahan pewarna congo red (Gambar 2).

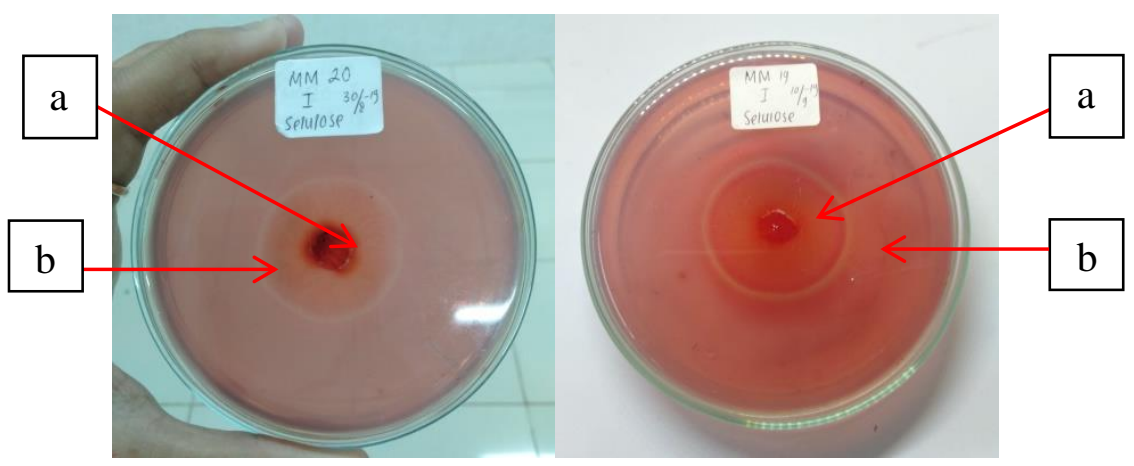

Gambar 2. Hasil positif uji aktivitas enzim selulase secara kualitatif pada isolat kapang endofit asal tanaman pegagan. ket : (a)Isolat (b)Zona bening 
Tabel 2. Diameter zona bening kapang endofit penghasil enzim selulase

\begin{tabular}{|c|c|c|c|c|c|c|c|}
\hline \multirow[t]{2}{*}{ Isolat } & \multicolumn{2}{|c|}{ Hasil (+/-) } & \multicolumn{2}{|c|}{$\begin{array}{c}\text { Diameter zona } \\
\text { bening }(\mathrm{cm})\end{array}$} & \multicolumn{2}{|c|}{$\begin{array}{c}\text { Diameter } \\
\text { koloni }(\mathrm{cm})\end{array}$} & \multirow[t]{2}{*}{ Indeks } \\
\hline & I & II & I & II & I & II & \\
\hline Ceratobasidium sp MM 1 & + & + & 3,75 & 3,70 & 3,35 & 3,30 & 1,12 \\
\hline Phialemonium dimorphosporum $\mathrm{MM} 8$ & - & - & 0 & 0 & 0 & 0 & 0 \\
\hline Phanerochaete stereoides MM 12 & + & + & 3,45 & 3,25 & 3,10 & 3,10 & 1,08 \\
\hline Penicillium capsulatum MM 15 & - & - & 0 & 0 & 0 & 0 & 0 \\
\hline Talaromyces pinophilus MM 16 & + & + & 3,80 & 3,75 & 3,50 & 3,45 & 1,09 \\
\hline Colletotrichum tabaci MM 18 & + & + & 6,50 & 6,30 & 6,40 & 6,15 & 1,02 \\
\hline Chaetomium globosum MM 19 & + & + & 3,15 & 3,30 & 2,70 & 2,80 & 1,17 \\
\hline Fusarium striatum MM 20 & + & + & 3,20 & 3,15 & 3,00 & 3,00 & 1,06 \\
\hline Perenniporia corticola MM 21 & + & + & 6,20 & 6,30 & 6,00 & 6,20 & 1,02 \\
\hline Colletotrichum tabaci MM 23 & + & + & 4,40 & 5,00 & 3,25 & 3,60 & 1,37 \\
\hline
\end{tabular}

Keterangan : Indeks = diameter zona bening / diameter koloni

Congo red akan bereaksi dengan $\beta-1,4-$ glikosidik dalam media CMC. Setelah dilakukan pencucian menggunakan $\mathrm{NaCl} 0,1 \%$ zona bening yang terbentuk dapat dilihat dengan jelas, hal ini disbebkan karena congo red merupakan garam natrium dari benzidinediazo-bis-1naphthylamine-4 asam sulfonat $\left(\mathrm{C}_{32} \mathrm{H}_{22} \mathrm{~N}_{6} \mathrm{Na}_{2} \mathrm{O}_{6} \mathrm{~S}_{2}\right)$ yang akan tercuci dan larut oleh garam natrium lain karena adanya ion sejenis, seperti $\mathrm{NaCl}$ sehingga zona bening yang terbentuk akan terlihat jelas. Diameter zona bening kapang endofit penghasil enzim selulase dari masing-masing isolat dapat dilihat pada Tabel 2.

Uji aktivitas selulolitik kapang endofit dilakukan secara kualitatif dengan media selektif CMC yang diuji terhadap sepuluh isolat kapang, dari hasil pengujian diketahui bahwa terdapat delapan isolat yang mempunyai aktivitas selulolik berdasarkan adanya zona bening disekitar koloni. Pada Tabel 2 dapat dilihat bahwa setiap isolat memiliki indeks diameter zona bening yang berbeda-beda. Berdasarkan pengujian, indeks diameter zona bening tertinggi yaitu isolat Colletotrichum tabaci MM 23 sedangkan isolat yang memiliki indeks diameter zona bening terendah yaitu isolat Colletotrichum tabaci MM18 dan Perenniporia corticola MM 21. Terbentuknya zona bening mengindikasikan bahwa selulosa yang terdapat didalam media CMC dihidrolisis oleh enzim selulase menjadi senyawa yang lebih sederhana yaitu selobiosa, kemudian akan kembali disederhanakan menjadi dua molekul glukosa.

\section{Uji Kapang Endofit Penghasil Enzim Glukanase secara Kualitatif}

Berdasarkan hasil pengujian glukanolitik pada media glukan menunjukkan adanya aktivitas enzim glukanase yang ditandai dengan adanya visualisasi berupa zona bening disekitar koloni kapang uji setelah diinkubasi selama 5-7 hari pada suhu ruang (Gambar 3). Zona bening yang terbentuk setelah digenangi pewarna congo red disebabkan karena adanya hidrolisis substrat glukan yang terdapat di dalam medium selektif oleh glukanase yang terdapat pada kapang. Penambahan congo red dalam media akan membunuh bakteri yang hidup pada media tersebut karena congo red bersifat karsinogenik, sehingga hanya akan tersisa visualisasi zona bening yang menandakan bahwa substrak glukan pada media selektif tersebut telah dikonsumsi oleh kapang endofit.

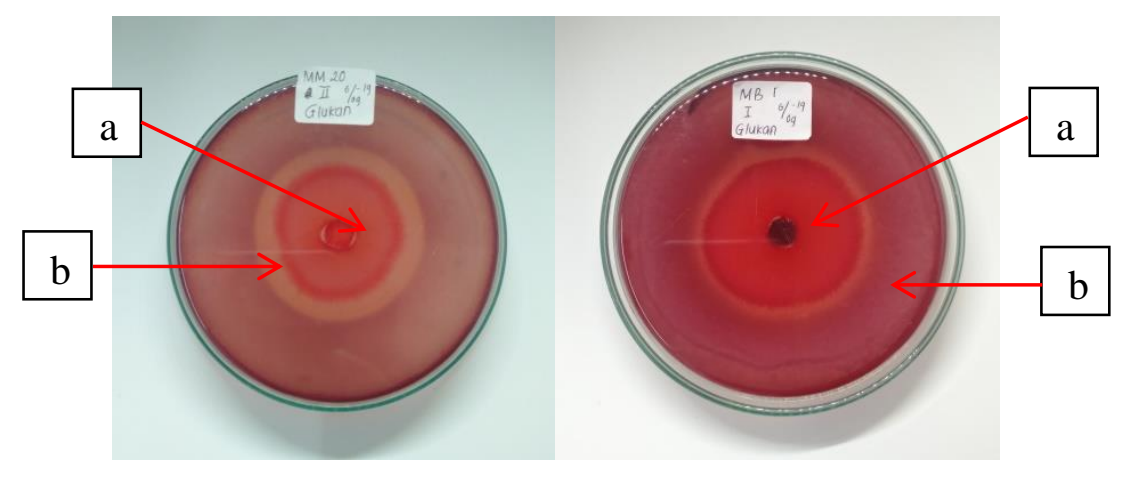

Gambar 3. Hasil positif uji aktivitas enzim glukanase secara kualitatif pada isolat kapang endofit asal tanaman pegagan. ket : (a) Isolat (b) Zona bening 
Tabel 3. Diameter zona bening kapang endofit penghasil enzim glukanase

\begin{tabular}{|c|c|c|c|c|c|c|c|}
\hline \multirow[t]{2}{*}{ Isolat } & \multicolumn{2}{|c|}{ Hasil (+/-) } & \multicolumn{2}{|c|}{$\begin{array}{l}\text { Diameter zona } \\
\text { bening }(\mathrm{cm})\end{array}$} & \multicolumn{2}{|c|}{$\begin{array}{l}\text { Diameter } \\
\text { koloni }(\mathrm{cm})\end{array}$} & \multirow[t]{2}{*}{ Indeks } \\
\hline & $\mathrm{I}$ & II & I & II & I & II & \\
\hline Aspergillus austroafricanus MB 1 & + & + & 5,20 & 5,25 & 4,05 & 4,00 & 1,30 \\
\hline Fusarium oxysporum MB 3 & + & + & 5,85 & 6,15 & 4,00 & 4,05 & 1,49 \\
\hline Acrocalymma vagum $\mathrm{MB} 4$ & + & + & 4,50 & 4,20 & 2,55 & 2,60 & 1,69 \\
\hline Acrocalymma vagum $\mathrm{MB} 6$ & + & + & 5,30 & 5,55 & 3,90 & 4,00 & 1,37 \\
\hline Ceratobasidium sp. MM 1 & + & + & 3,50 & 2,85 & 3,20 & 2,50 & 1,11 \\
\hline Phyllosticta capitalensis MM 7 & - & - & 0 & 0 & 0 & 0 & 0 \\
\hline Phialemonium dimorphosporum MM 8 & - & - & 0 & 0 & 0 & 0 & 0 \\
\hline Collectotrichum siamense MM 9 & + & + & 3,55 & 3,50 & 2,90 & 2,30 & 1,36 \\
\hline Phomopsis asparagi MM 11 & + & + & 7,55 & 7,50 & 6,55 & 6,55 & 1,15 \\
\hline Phanerochaete stereoides MM 12 & - & - & 0 & 0 & 0 & 0 & 0 \\
\hline Aspergillus oryzae MM 13 & + & + & 8,30 & 4,00 & 4,25 & 3,20 & 1,65 \\
\hline Colletotrichum gigasporum MM 14 & + & + & 6,75 & 6,60 & 4,25 & 4,35 & 1,49 \\
\hline Talaromyces pinophilus MM 16 & + & + & 2,75 & 2,70 & 2,50 & 2,45 & 1,10 \\
\hline Fusarium solani MM 17 & - & - & 0 & 0 & 0 & 0 & 0 \\
\hline Chaetomium globosum MM 19 & + & + & 3,25 & 3,30 & 3,00 & 3,10 & 1,07 \\
\hline Fusarium stiatum MM 20 & + & + & 4,75 & 5,00 & 3,45 & 3,25 & 1,46 \\
\hline Perenniporia corticola MM 21 & + & + & 6,35 & 6,00 & 4,65 & 4,55 & 1,34 \\
\hline Fusarium falciforme MM 22 & - & - & 0 & 0 & 0 & 0 & 0 \\
\hline Colletotrichum tabaci MM 23 & - & - & 0 & 0 & 0 & 0 & 0 \\
\hline
\end{tabular}

Keterangan : Indeks = diameter zona bening / diameter koloni

Pada Tabel 3 dapat dilihat bahwa sebanyak 13 isolat yang diuji menunjukkan adanya aktivitas glukanolitik, sedangkan 6 isolat lainya tidak menunjukan tidak adanya aktivitas glukanolitik. Setiap isolat memiliki indeks diameter zona bening yang berbeda-beda. Berdasarkan tingginya angka indeks dari masingmasing isolat yang diamati maka yang memiliki angka indeks tertinggi yaitu isolat Acrocalymma vagum $\mathrm{MB} 4$ sedangkan isolat yang memiliki angka indeks terendah yaitu isolat Chaetomium globosum MM 19.

\section{Uji Kapang Endofit Penghasil Enzim Lakase secara Kualitatif}

Hasil pengamatan uji kualitatif menunjukkan tidak adanya aktivitas enzim lakase pada 12 isolat yang diuji. Hal ini terbukti karena tidak terbentuknya aktivitas enzim lakkase berupa visualisasi zona bening disekitar koloni setelah diberi larutan 1-Napthol (Gambar 4).

Sangat sedikit kapang endofit pegagan sebagai penghasil enzim lakase. Hal ini didukung dengan hasil penelitian Sunitha et al. (2013), yang menjelaskan bahwa kapang endofit pegagan sedikit sekali yang dapat menghasilkan enzim lakase ekstraseluler. Maria et al. (2005) juga menyatakan bahwa kapang endofit yang berhasil diisolasi tidak satupun yang dapat menghasilkan enzim lakase. Kondisi dimana kapang endofit pegagan tidak menghasilkan enzim lakase kemungkinan disebabkan oleh sifat dari kapang endofitnya, sehingga tidak banyak atau bahkan tidak ada yang menghasilkan enzim lakase. Aktivitas enzim lakase pada tanaman dapat menyebabkan kerusakan pada inang tanaman kapang endofit tersebut.

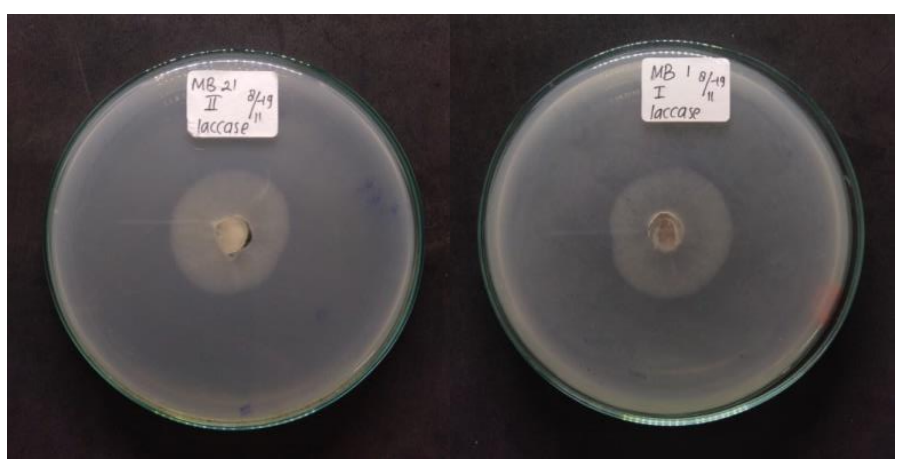

Gambar 4. Hasil negatif uji aktivitas enzim lakase secara kualitatif pada isolat kapang endofit asal tanaman pegagan. 
Tabel 4. Diameter zona bening kapang endofit penghasil enzim lakase

\begin{tabular}{|c|c|c|c|c|c|c|c|}
\hline \multirow[t]{2}{*}{ Isolat } & \multicolumn{2}{|c|}{ Hasil (+/-) } & \multicolumn{2}{|c|}{$\begin{array}{c}\text { Diameter zona } \\
\text { bening }(\mathrm{cm})\end{array}$} & \multicolumn{2}{|c|}{$\begin{array}{l}\text { Diameter koloni } \\
(\mathrm{cm})\end{array}$} & \multirow[t]{2}{*}{ Indeks } \\
\hline & I & II & I & II & I & II & \\
\hline Aspergillus austroafricanus MB 1 & - & - & 0 & 0 & 0 & 0 & 0 \\
\hline Perenniporia tephropora MB 5 & - & - & 0 & 0 & 0 & 0 & 0 \\
\hline Fusarium falciforme MB 8 & - & - & 0 & 0 & 0 & 0 & 0 \\
\hline Trichaptum sp. MB 11 & - & - & 0 & 0 & 0 & 0 & 0 \\
\hline Fusarium keratoplasticum MB 12 & - & - & 0 & 0 & 0 & 0 & 0 \\
\hline Fusarium keratoplasticum MB 15 & - & - & 0 & 0 & 0 & 0 & 0 \\
\hline Fusarium oxysporum MB 17 & - & - & 0 & 0 & 0 & 0 & 0 \\
\hline Collectricum tabaci MB 18 & - & - & 0 & 0 & 0 & 0 & 0 \\
\hline Mycochaetophora gentiance MB 19 & - & - & 0 & 0 & 0 & 0 & 0 \\
\hline Mycochaetophora gentianae MB 21 & - & - & 0 & 0 & 0 & 0 & 0 \\
\hline Ceratobasidium sp. MM 1 & - & - & 0 & 0 & 0 & 0 & 0 \\
\hline Phanerochaete stereoides MM 12 & - & - & 0 & 0 & 0 & 0 & 0 \\
\hline
\end{tabular}

Keterangan : Indeks = diameter zona bening / diameter koloni

\section{Uji Kapang Endofit Penghasil Enzim Pektinase secara Kualitatif}

Pengamatan aktivitas pektinolitik dilakukan dengan menumbuhkan isolat kapang pada media selektif yang mengandung substrat pektin. Penggunaan substrat bertujuan agar dapat menginduksi jamur kapang untuk menghasilkan enzim pektinase. Namun, Berdasarkan hasil pengamatan uji kualitatif menunjukkan tidak adanya aktivitas enzim pektinase pada 13 isolat yang diuji pada media selektif. Hal ini terbukti karena tidak terbentuknya visualisasi berupa zona bening disekitar koloni setelah diberi penambahan larutan hexadecyl trimetil ammonium bromida (Gambar 5).
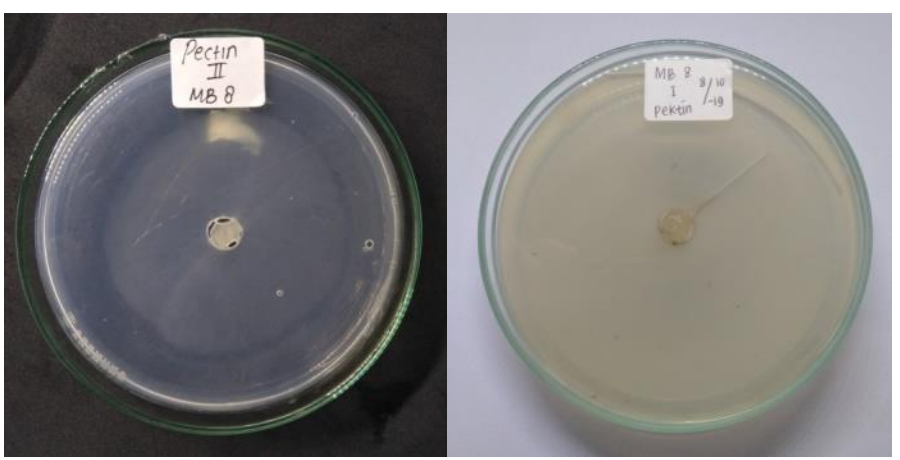

Gambar 5. Hasil negatif uji aktivitas enzim pektinase secara kualitatif pada isolat kapang endofit asal tanaman pegagan

Tabel 5. Diameter zona bening kapang endofit penghasil enzim pektinase

\begin{tabular}{|c|c|c|c|c|c|c|c|}
\hline \multirow[t]{2}{*}{ Isolat } & \multicolumn{2}{|c|}{ Hasil (+/-) } & \multicolumn{2}{|c|}{$\begin{array}{c}\text { Diameter zona } \\
\text { bening }(\mathrm{cm})\end{array}$} & \multicolumn{2}{|c|}{$\begin{array}{l}\text { Diameter koloni } \\
(\mathrm{cm})\end{array}$} & \multirow[t]{2}{*}{ Indeks } \\
\hline & I & II & I & II & I & II & \\
\hline Fusarium falciforme MB 8 & - & - & 0 & 0 & 0 & 0 & 0 \\
\hline Ceratobasidium sp. MM 1 & - & - & 0 & 0 & 0 & 0 & 0 \\
\hline Colletotrichum karstii MM 2 & - & - & 0 & 0 & 0 & 0 & 0 \\
\hline Phialemonium dimorphosporum MM 8 & - & - & 0 & 0 & 0 & 0 & 0 \\
\hline Collectotrichum siamense MM 9 & - & - & 0 & 0 & 0 & 0 & 0 \\
\hline Phanerochaete stereoides MM 12 & - & - & 0 & 0 & 0 & 0 & 0 \\
\hline Collectotrichum gigasporum MM 14 & - & - & 0 & 0 & 0 & 0 & 0 \\
\hline Penicillium capsulatum MM 15 & - & - & 0 & 0 & 0 & 0 & 0 \\
\hline Talaromyces pinophilus MM 16 & - & - & 0 & 0 & 0 & 0 & 0 \\
\hline Chaetomium globosum MM 19 & - & - & 0 & 0 & 0 & 0 & 0 \\
\hline Fusarium striatum MM 20 & - & - & 0 & 0 & 0 & 0 & 0 \\
\hline Perenniporia corticola MM 21 & - & - & 0 & 0 & 0 & 0 & 0 \\
\hline Colletotrichum tabaci MM 23 & - & - & 0 & 0 & 0 & 0 & 0 \\
\hline
\end{tabular}

Keterangan : Indeks = diameter zona bening / diameter koloni 


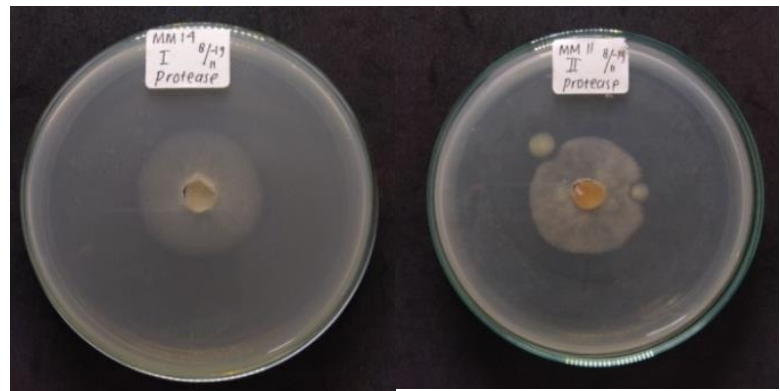

Gambar 6. Hasil negatif uji aktivitas enzim protease secara kualitatif pada isolate kapang endofit asal tanaman pegagan.

Tabel 6. Diameter zona bening kapang endofit penghasil enzim protease

\begin{tabular}{|c|c|c|c|c|c|c|c|}
\hline \multirow[t]{2}{*}{ Isolat } & \multicolumn{2}{|c|}{ Hasil (+/-) } & \multicolumn{2}{|c|}{$\begin{array}{l}\text { Diameter zona } \\
\text { bening }(\mathrm{cm})\end{array}$} & \multicolumn{2}{|c|}{$\begin{array}{l}\text { Diameter } \\
\text { koloni }(\mathrm{cm})\end{array}$} & \multirow[t]{2}{*}{ Indeks } \\
\hline & I & II & I & II & I & II & \\
\hline Ceratobasidium sp. MM 1 & - & - & 0 & 0 & 0 & 0 & 0 \\
\hline Phialemonium dimorphosporum MM 8 & - & - & 0 & 0 & 0 & 0 & 0 \\
\hline Peroneutypa scoparia MM 10 & - & - & 0 & 0 & 0 & 0 & 0 \\
\hline Phomopsis asparagi MM 11 & - & - & 0 & 0 & 0 & 0 & 0 \\
\hline Phanerochaete stereoides MM 12 & - & - & 0 & 0 & 0 & 0 & 0 \\
\hline Aspergillusoryzae MM 13 & - & - & 0 & 0 & 0 & 0 & 0 \\
\hline Colletotrichum gigasporum MM 14 & - & - & 0 & 0 & 0 & 0 & 0 \\
\hline Fusarium solani MM 17 & - & - & 0 & 0 & 0 & 0 & 0 \\
\hline Chaetomium globosum MM 19 & - & - & 0 & 0 & 0 & 0 & 0 \\
\hline
\end{tabular}

Keterangan : Indeks = diameter zona bening / diameter koloni

\section{Uji Kapang Endofit Penghasil Enzim Protease secara Kualitatif}

Uji aktivitas proteolitik dilakukan pada 9 isolat kapang endofit dengan menggunakan media selektif. Uji positif ditunjukan dengan adanya zona bening disekitar koloni kapang pada media selektif. Namun pada uji kali ini tidak ditemukan adanya aktivitas proteolitik dari ke sembilan isolat kapang. Terbukti karena tidak adanya visualisasi berupa zona bening disekitar koloni setelah diberi penambahan larutan ammonium sulfat jenuh (Gambar 6), hal ini dikarenakan tidak terdapat enzim ekstraseluler protease pada isolat kapang yang di uji, sehingga substrat protein yang terkandung dalam media selektif tidak dapat terhidrolisis dan membentuk zona bening.

\section{Deteksi Siderofor yang Dihasilkan oleh Kapang Endofit Tanaman Pegagan}

Hasil penelitian menunjukkan bahwa empat dari sembilan isolat kapang endofit yang telah diuji mampu menghasilkan siderofor berdasarkan pengujian secara kualitatif. Pada isolat Aspergillus austroafricanus MB 1 dan Talaromyces pinophilus MM 16 dihasilkan zona oranye dengan ukuran zona lebih kecil dibandingkan zona dari Ceratobasidium cornigerum MB 20 dan Colletotrichum gigasporum MM 14 yang menghasilkan zona oranye lebih besar. Ukuran zona oranye yang terbentuk menunjukkan kuat atau lemahnya kapang endofit pegagan sebagai penghasil siderofor.

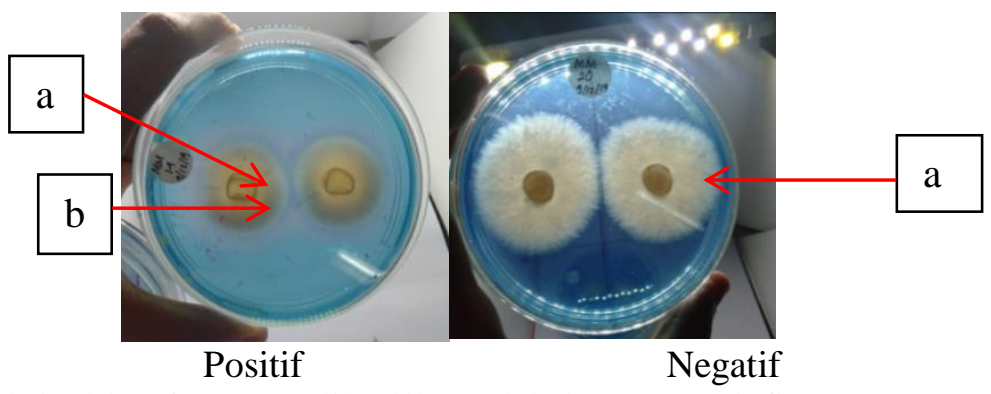

Gambar 7. Hasil deteksi Siderofor yang dihasilkan oleh kapang endofit tanaman pegagan. ket : (a) Isolat (b) zona bening oranye 
Tabel 7. Deteksi Siderofor yang Dihasilkan oleh kapang endofit tanaman pegagan

\begin{tabular}{lcc}
\hline \multicolumn{1}{c}{ Isolat } & Deteksi Siderofor & Warna Zona \\
\hline Aspergillus austroafricanus MB 1 & + & Oranye \\
Fusarium oxysporum MB 3 & - & - \\
Ceratobasidium cornigerum MB 20 & ++ & Oranye \\
Collectotrichum siamense MM 9 & - & - \\
Phomopsis asparagi MM 11 & - & - \\
Colletotrichum gigasporum MM 14 & ++ & Oranye \\
Talaromyces pinophilus MM 16 & + & Oranye \\
Fusarium stiatum MM 20 & - & - \\
\hline$+:$ menghasilkan siderofor sedang, $++:$ menghasilkan siderofor kuat
\end{tabular}

Kemampuan mikroba menghasilkan siderofor merupakan komponen penting dalam PGPR (Plant Growth Promoting Rhizhobacteria), karena siderofor mampu bereaksi dengan besi $\left(\mathrm{Fe}^{3+}\right)$ dan mengikatnya menjadi ikatan besi-siderofor yang bermanfaat bagi tanaman karena besi merupakan elemen penting dalam perkembangan infeksi. Tanaman akan diuntungkan dengan adanya siderofor yang dihasilkan oleh mikroorganisme karena dapat menghambat pertumbuhan patogen, dengan mekanisme $\mathrm{Fe}^{3+}$ akan diikat oleh siderofor sehingga terjadi kekurangan $\mathrm{Fe}^{3+}$ yang dibutuhkan oleh patogen sehingga patogen kurang mampu menginfeksi dan menghambat perkembangan penyakit (Sharma \& Johri, 2003)

\section{Pengamatan Mikroskopis}

Beberapa jenis kapang endofit yang telah terbukti positif sebagai penghasil enzim ekstraseluler kemudian dilanjutkan dengan pengamatan mikroskopis. Beberapa jenis kapang tersebut adalah Aspergillus austroafricanus MB 1, Fusarium oxysporum MB 3, Acrotobasidium cornigerum MB 4, MB 6, Ceratobasidium sp. MM 1, Phialemonium dimorphosporum MM 8, Collectotrichum siamense MM 9, Phomopsis asparagi MM 11, Colletotrichum gigasporum MM 14, Talaromyces pinophilus MM 16, Chaetomium globosum MM 19, Fusarium striatum MM 20, Colletotrichum tabaci MM 23. Pengamatan mikroskopis dilakukan menggunakan mikroskop cahaya pada pembesaran 40x dan 100x. Kaca objek dan kaca penutup terlebih dahulu dibersihkan dengan alkohol 70\%. Isolat diambil dan diurai menggunakan tusuk gigi steril dengan media lacto cotton blue dan diberi setetes ethanol. Setelah itu kaca penutup diletakkan di atas permukaan gelas objek kemudian difiksasi terlebih dahulu sebelum diamati menggunakan mikroskop. Dokumentasi hasil pengamatan mikroskopis dapat dilihat pada Lampiran.

\section{KESIMPULAN}

Berdasarkan analisis yang telah dilakukan di peroleh kesimpulan, yaitu : (1) Kapang endofit asal tanaman pegagan dengan kode isolat MB 20, MM 1, MM 6, MM 8 dan MM 16 mampu menghasilkan enzim amilase ekstraseluler. (2) Kapang endofit asal tanaman pegagan dengan kode isolat MM 1, MM 12, MM 16, MM 18, MM 19, MM 20 dan MM 21 mampu menghasilkan enzim selulase ekstraseluler. (3) Kapang endofit asal tanaman pegagan dengan kode isolat MB 1, MB 3, MB 4, MB 6, MM 1, MM 9, MM 11, MM 13, MM 14, MM16, MM 19, MM 20 dan MM 21 mampu menghasilkan enzim glukanase ekstraseluler. (4) Isolat kapang endofit asal tanaman pegagan terbukti tidak mampu menghasilkan enzim ekstraseluler lakase, pektinase dan protease. (4) Kapang endofit asal tanaman pegagan dengan kode isolat MB 1, MB 20, MM 14 dan MM 16 mampu menghasilkan siderofor.

\section{UCAPAN TERIMA KASIH}

Terimakasih penulis sampaikan kepada Ibu Retno Aliyatul Fikroh, M. Sc yang telah mendukung penulis, dan kepada kedua orang tua saya yang selalu mendoakan yang terbaik bagi penulis.

\section{DAFTAR PUSTAKA}

Bermawie, N., Purwiyanti, S., \& Mardiana, M. (2008). Keragaan sifat morfologi, hasil dan mutu plasma nutfah pegagan (Centella asiatica (L.) Urban.). Bul. Littro. Vol. XIX No. 1, 2008, 1 -17

Choi, Y., Hodgkiss, I., \& Hyde, K. (2005). Enzyme production by endophytes of 
Brucea javanica. J Agric Technol, 1, 5566.

Devi, N. N., Prabakaran, J. J., \& Wahab, F. (2012). Phytochemical analysis and enzyme analysis of endophytic fungi from Centella asiatica. Asian Pacific Journal of Tropical Biomedicine, 2(3), S1280-S1284.

Jia, M., Chen, L., Xin, H.-L., Zheng, C.-J., Rahman, K., Han, T., \& Qin, L.-P. (2016). A friendly relationship between endophytic fungi and medicinal plants: A systematic review. Frontiers in microbiology, 7, 906.

Latifasari, N., Naufalin, R., \& Wicaksono, R. (2019). Edible coating application of kecombrang leaves to reduce gourami sausage damage. 250(1), 012055.

Mainawati, D., Brahmana, E. M., \& Mubarrak, J. (2017). Uji Kandungan Metabolit Sekunder Tumbuhan Obat Yang terdapat Di Kecamatan Rambah Samo Kabupaten Rokan Hulu. Media Neliti, 1-6.

Maria, G., Sridhar, K., \& Raviraja, N. (2005). Antimicrobial and enzyme activity of mangrove endophytic fungi of southwest coast of India. Journal of Agricultural technology, 1(1), 67-80.

Muhlisah, F. (2007). Tanaman obat keluarga toga. Penebar Swadaya : Jakarta

Murdiyah, S. (2017). Fungi Endofit Pada Berbagai Tanaman Berkhasiat Obat Di Kawasan Hutan Evergreen Taman Nasional Baluran Dan Potensi
Pengembangan Sebagai Petunjuk Parktikum Mata Kuliah Mikologi. 3(1), 1-10.

Pelczar, M. J. (2019). Dasar-dasar mikrobiologi. Universitas Indonesia : Jakarta. Pustaka Poltekkes Padang Collection.

Rahayu, A. G., Haryani, Y., \& Puspita, F. (2014). Uji aktivitas selulolitik dari tiga isolat bakteri Bacillus sp. Galur lokal Riau. JOM FMIPA. 1(2), 319-327.

Rana, K. L., Kour, D., Sheikh, I., Yadav, N., Yadav, A. N., Kumar, V., Singh, B. P., Dhaliwal, H. S., \& Saxena, A. K. (2019). Biodiversity of endophytic fungi from diverse niches and their biotechnological applications. Advances in endophytic fungal research, 105-144.

Shubhpriya Gupta and Preeti Chaturvedi. (2017). Foliar Endophytic Diversity of Centella asiatica (L.) Urban in Relation to Different Seasons and Leaf AgeInt.J.Curr.Microbiol.App.Sci. 6(6), 468-477.

Sunitha, V., Nirmala Devi, D., \& Srinivas, C. (2013). Extracellular enzymatic activity of endophytic fungal strains isolated from medicinal plants. World Journal of Agricultural Sciences, 9(1), 1-9.

Theantana, T., Hyde, K. D., \& Lumyong, S. (2009). Asparaginase production by endophytic fungi from Thai medicinal plants: Cytotoxicity properties. International Journal of Integrative Biology, 7(1), 1-8. 